\title{
Analysis and characterization of the Composition of construction waste in the city of Ribeirão Preto- SP
}

\author{
Análise e caracterização da Composição dos resíduos da \\ construção civil no município de Ribeirão Preto-SP
}

\author{
Luiz Paulo da Silva ${ }^{1}$ (D), José da Costa Marques Neto ${ }^{1,2}$ (D) \\ ${ }^{1}$ Universidade Federal de São Carlos - UFSCar, Programa de Pós-graduação em Estruturas e Construção Civil - \\ PPGECiv, São Carlos, SP, Brasil. E-mail: silvaluizpaulo1@gmail.com; joseneto@ufscar.br \\ ${ }^{2}$ Universidade de São Paulo - USP. São Carlos, SP, Brasil
}

How to cite: Silva, L. P., \& Marque Neto, J. C. (2021). Analysis and characterization of the Composition of construction waste in the city of Ribeirão Preto- SP. Gestão \& Produção, 28(4), e5237.

https://doi.org/10.1590/1806-9649-2020v28e5237

\begin{abstract}
With an accelerated economic and social development, the growing generation of solid waste produced by society, whether domestic, urban, hospital, industrial or construction, is highlighted. To do so, it is highlighted what to do and how to manage this problem, in order to reduce environmental impacts and take advantage of such waste. In this context, the present study aims to determine the composition of waste in the city of Ribeirão Preto-SP, through a quantitative and qualitative research, seeking to present the percentage composition of each material found in the city's buckets, through collection and weighing. With this, analyzing the composition of the buckets, the unit mass of $0.79 \mathrm{t} / \mathrm{m}^{3}$ was determined. The work also pointed out the main areas of clandestine discards in the city of Ribeirão Preto and organized in the form of an inventory. Therefore, the work seeks to identify the composition of construction waste and provide information and values to support future studies.
\end{abstract}

Keywords: Buckets; Composition; Construction; Economic development; Solid waste,

Resumo: O acelerado desenvolvimento econômico, social e tecnológico nos últimos anos, fezse, destacar a crescente geração de resíduos sólidos produzidos pela sociedade, sejam esses, domésticos, urbanos, hospitalares, industriais ou da construção civil. Criando assim uma séria questão a ser repensada. O que fazer e como gerenciar esse problema, visando reduzir os impactos ambientais e aproveitar esses resíduos? Nesse contexto, o presente trabalho teve como objetivo determinar a composição dos resíduos da construção civil, na cidade de Ribeirão Preto-SP, através de uma pesquisa quantitativa e qualitativa, buscando apresentar a composição percentual de cada material encontrado em caçambas da cidade, através de coleta e pesagem. Em seguida foi analisado a composição das caçambas, com um valor já pré determinado da massa unitária de $0,79 \mathrm{t} / \mathrm{m}^{3}$. O trabalho apontou também, as principais áreas de descartes clandestinos na cidade de Ribeirão Preto, que foi organizado em forma de um inventário. Com foco na construção civil o trabalho buscou identificar a composição dos resíduos sólidos, fornecer informações e valores para embasar futuros estudos.

Palavras-chave: Caçambas; Composição; Construção civil; Desenvolvimento econômico; Resíduos sólidos.

Received Sep. 14, 2019 - Accepted Mar. 21, 2020

Financial support: None.

This is an Open Access article distributed under the terms of the Creative Commons Attribution License, which permits unrestricted use, distribution, and reproduction in any medium, provided the original work is properly cited. 


\title{
1 Introduction
}

The construction activity is fundamental for the growth and development of cities, thus also generating a great environmental impact, due to the irregular disposal of construction and demolition waste. For this reason, Civil Construction Waste has been the subject of several studies to better understand the forms of generation, management and disposal, seeking to solve the problems faced by Brazilian cities.

Construction Waste, popularly called construction debris, is generally an inert but reusable material, being defined as the rest of materials derived from buildings, renovations or other activities in the chain that are no longer useful for it.

In the Brazilian context, construction waste is defined in technical terms by CONAMA Resolution No. 307 (Brasil, 2002, p. 1), defining as:

\begin{abstract}
Residues from construction: are those from the construction, renovation, repair and demolition of construction works, and resulting from the preparation and excavation of land, such as: bricks, ceramic blocks, concrete in general, soils, rocks, metals, resins, glues, paints, wood and plywood, ceilings, mortar, plaster, tiles, asphalt pavement, glass, plastics, piping, electrical wiring etc., commonly referred to as construction rubble, slag or shrapnel.
\end{abstract}

According to Córdoba (2010), in technical standards NBR 15.112 (ABNT, 2004b), NBR 15.113 (ABNT, 2004c), NBR 15.114 (ABNT, 2004d), NBR 15.115 (ABNT, 2004e), NBR 15.116 (ABNT, 2004f), which uses chemical substances for construction waste, defines a similar form to CONAMA Resolution 307/2002 and allows the term CW (Construction Waste) to be refer to residential waste from construction and demolition sites.

The National Solid Waste Policy of 2010 defined civil construction waste in section 13 as all that generated in construction, renovations, demolitions and repairs of civil works, also framing all material resulting from excavation of land and preparation of civil works.

According to CONAMA Resolution No. 307/2002, in its article 3 with its amendment of May 24, 2011, of Resolution No. 431 (Brasil, 2011), establishes a new classification for construction waste, as follows:

Class A: Waste from masonry, concrete and mortar remains. Wastes which may be reused, such as:

Remains of construction, demolition, renovations, paving of infrastructure works and earthmoving;

Remains of construction, demolition and renovation of buildings. Having as components remnants of ceramic materials, concrete and mortar;

Remains of the manufacturing and / or demolition process of precast concrete parts, such as blocks and tubes, which are produced at the construction site.

Class B: plastics, paper, cardboard, glass, metals, wood and plaster;

Class C: Waste for which no economically viable technologies or applications have been developed to enable recycling or recovery;

Class D: Waste derived from the construction process, considered as unsafe, such as:

Paints, oils and solvents;

Those contaminated or harmful to health from demolitions, renovations and repairs to radiological clinics, industrial facilities and others,

Materials containing earth-flax, such as roof tiles and other harmful products. 
According to the changes of CONAMA Resolution No. 448/2012 (Brasil, 2012), in its article 4, the generator becomes responsible for the segregation performed at the origin or to be carried out in the destination areas in areas licensed for this activity, respecting the different classes of $\mathrm{CW}$, forwarding for recycling, treatment or final disposal.

According to Levy (1997), the origin of the CW is given by the following actions:

Natural or artificial disasters;

Demolitions of road pavements made of concrete or of works that have already reached their useful life;

Due to the low quality of the workforce that causes a deficiency in the construction processes employed.

According to Leite (2001), the origin of the CW was linked, in the past, even with the great world wars, as about 400 to 600 million cubic meters of rubble were generated in German cities by the end of World War II. The need arose to reuse the waste generated for the reconstruction of the large urban centers of the country, as there were no places for the disposal of the huge amount of debris generated.

For Tavares (2007), an origin of CWs often gives problems in construction processes, such as failures in project execution, execution, use of low quality materials, loss in storage and transportation, incorrect manipulation of materials.

CONAMA Resolution No. 307 (Brasil, 2002) defines CW as to origin:

- Remains of building materials and new infrastructure works;

- Remains of building renovation and repair materials;

- Remains of building demolitions;

- Remains of earthmoving materials.

According to Castro et al. (1998), in the search for strategies that aim to reduce, reuse and reuse the construction waste generated, it is of fundamental importance to know the physical components of the $\mathrm{CW}$, trying to reduce the extraction of natural resources.

According to Carneiro et al (2001), the characterization of the CW can be represented by the following components:

- Concrete, mortar and rocks;

- Ceramic materials,

- Soils and sand;

- Asphalt;

- Ferrous metals;

- Wood;

- Plastics, papers, cardboard and rubbers.

Analyzing and characterizing the composition of construction waste in a municipality is a major and primordial factor to understand the problem and seek the appropriate solutions. Thus, it is possible to determine which materials are more prevalent in the buckets and thus understand the critical points of construction waste in the municipality under study, since the object of study is composed of materials with high variability, thus resulting in different values and solutions for each municipality.

The main objective of the present study is to determine the composition of construction waste in the city of Ribeirão Preto-SP and to verify the critical points in the city for clandestine disposal. 
To determine the main objective of the present study, some specific objectives were determined:

- Survey of authorized areas for the disposal of CW in Ribeirão Preto;

- Quantitative CW survey over a 4-month period in the area chosen for the study;

- Determination of unit mass;

\section{Materials and methods}

In the development of the study will be used a methodology already established by several authors, taking into consideration the quantitative survey of areas authorized for the receipt of municipal construction waste. The qualitative characteristics of the $\mathrm{CW}$ will be sorting and weighing materials from at least three buckets found in the landfill under study. The work will be performed at Reciclax company and will use a sand sieve to separate the smallest material and a digital scale.

The first part of the methodology is to carry out a survey of the areas authorized for the disposal of construction waste in the city of Ribeirão Preto, through a survey at the Secretariat of the Environment. In the second part of the methodology, one of the areas for field research will be determined. At this stage, will be selected a company that operates in the municipality receiving and sorting construction waste.

In the third part, a quantitative survey of the number of buckets received in the company over a period of 4 months will be carried out, through the physical invoices. At this stage, the research will take place in the field, interviewing employees and analyzing bucket entry and exit documents during the period in question.

In the fourth stage of the methodology, the composition of the CW in Ribeirão Preto, the information gathering will take place in the field through the following sequences:

- Select 3 buckets, discarded in the deposit;

- Collect 5 samples from $18 \mathrm{~L}$ each bucket;

- Gather the 5 samples in $90 \mathrm{~L}$ sample per bucket;

- Gather the 3 samples of 270L;

- Separate the components;

- Measure mass and volume;

- Determine the percentage of material composition;

- Determination of CW unit mass in Ribeirão Preto-SP

The determination of the mass of the $\mathrm{CW}$ components will be made by weighing each item found in the buckets under study through a Segma brand scale, model $40 \mathrm{Kg}$.

The fifth step of the methodology will be the survey of clandestine disposal areas in Ribeirão Preto, through a detailed search of environmentally incorrect disposal locations. All of these areas will be indicated by mapping and a inventory.

After surveys of the actual situation of $\mathrm{CW}$ in the city of Ribeirão Preto and with the diagnosis made, strategies will be studied for a CW management model based on CONAMA 307 resolution, aiming to reduce, reuse and recycle the generated waste, providing guidelines for the municipality and the builders involved in the process. 


\section{Results and discussions}

The qualitative characterization of construction waste is a fundamental part of the analysis of the waste diagnosis in the city under study. Thus, it is possible to identify and recognize the main components of a bucket, as well as to provide indicators for the study.

According to Marques (2003), the composition of the CW is one of the most important stages of the diagnosis, because from the types of materials and their percentages it is possible to propose new strategies for recycling and control of the $\mathrm{CW}$.

\subsection{Survey of authorized CW disposal áreas}

Ribeirão Preto currently has eleven licensed and authorized points for the disposal of construction waste, including five transhipment and sorting areas (ATT) and six CW recycling plants. From these points, only one recycling plant is under the administration of the government, the others being the responsibility of the private sector. In the present study the five transhipment and sorting areas will be named respectively, ATT-A, ATT-B, ATT-C, ATT-D and ATT-E and the six plants of PLANT-A, PLANT-B, PLANT-C, PLANT-D, PALNT-E and PLANT-F. These denominations were adopted in order to preserve the names and social reasons of the respective companies, since the purpose of the research is to determine the composition of construction waste and not to disclose the companies involved in the sector.

\subsection{Determination of an area authorized for the study}

According to the established methodology, PLANT-B was selected to collect and conduct field research. Currently the PLANT-B area is divided into seven courtyards through which the distribution and logistics for waste management are made. Upon arrival, the buckets are deposited in one of the courtyards, which there with CTR and through trained employees are classified according to the company's criteria.

\subsection{Quantitative USINA-B Survey}

Over a period of 4 months, the volumes of construction waste were analyzed and quantified by the number of buckets received in the given study period. This survey was conducted in 2016 in September, October, November and December. To facilitate control, this survey was performed by checking and consulting the invoices of each bucket, according to Table 1 :

Table 1. Amount of CW in PLANT-B during the study period.

\begin{tabular}{cccccc}
\hline COLLECTOR & $\begin{array}{c}\text { SEPTEMBER } \\
\left(\mathbf{M}^{3}\right)\end{array}$ & $\begin{array}{c}\text { OCTOBER } \\
\left(\mathbf{M}^{3}\right)\end{array}$ & $\begin{array}{c}\text { NOVEMBER } \\
\left(\mathbf{M}^{3}\right)\end{array}$ & $\begin{array}{c}\text { DECEMBER } \\
\left(\mathbf{M}^{3}\right)\end{array}$ & $\begin{array}{c}\text { TOTAL } \\
\left(\mathbf{M}^{3}\right)\end{array}$ \\
\hline PLANT-B & 1,905 & 2,313 & 2,050 & 749 & 7,017 \\
\hline
\end{tabular}

It is worth to note that these values are composed of class $A$, class $B$, class $C$ and class D waste, according to the classification of CONAMA Resolution 307/2002 (Brasil, 
2002), as the plant under study restricts some materials such as organic waste, hospital waste, receiving only waste from construction.

This survey took into consideration only the working days of the month, excluding Saturdays, Sundays and holidays, during which the plant did not operate. Thus, in September were considered 21 days, in October 20 days, in November 20 days and finally, in December 22 days.

\subsection{Determination of CW composition in Ribeirão Preto}

According to the specified methodology, in the PLANT-B yard 3 buckets with a capacity of $3 \mathrm{~m}^{3}$ each were selected, seeking to select the buckets with the most varied aspects in their composition.

Next, five 18-liter samples were taken from each bucket, totaling 90 liters each. The samples were taken from different points of the bucket, covering the entire physical space. After joining, 390 liter samples were formed and joined together for a 270 liter sample.

Following the methodology, the materials were cleaned and separated by type. With the help of a sand sieve, the materials with the highest particle size were separated from the smaller ones, and after that, the weighing was performed according to Table 2.

Table 2 below shows the masses of each material found in the bucket CW:

Table 2. Bucket Composition.

\begin{tabular}{ccccc}
\hline Material & Bucket 1 & Bucket 2 & Bucket 3 & Total \\
\hline Concrete & 8.3 & 23 & 5.17 & 36.47 \\
\hline Mortar & 18.33 & 2.56 & 6.93 & 27.82 \\
\hline Pottery & 17.82 & 1.32 & 5.48 & 24.62 \\
\hline Sand / Soil & 15.44 & 2.00 & 4.66 & 22.1 \\
\hline Stone & 2.52 & 3.52 & - & 6.04 \\
\hline Polished Ceramics & 0.63 & 26.09 & 23.8 & 50.52 \\
\hline Fiber cement & - & 3.45 & - & 3.45 \\
\hline Wood & 0.23 & 2.30 & 6.80 & 9.33 \\
\hline Iron & - & 0.5 & 0.48 & 0.98 \\
\hline Plaster & 1.26 & 1.36 & 8.30 & 10.92 \\
\hline Glass & 1.32 & 0.37 & 0.30 & 1.99 \\
\hline Plastic & 1.58 & 0.5 & 1.19 & 3.27 \\
\hline PVC & - & 2.19 & 1.41 & 3.6 \\
\hline Vegetation & 0.53 & - & 1.50 & 2.03 \\
\hline Paper / Cardboard & - & 1.05 & 0.3 & 1.35 \\
\hline Demolition brick & 4.06 & 4.55 & - & 8.61 \\
\hline TOTAL & $\mathbf{7 2 . 0 2}$ & $\mathbf{7 4 . 7 6}$ & $\mathbf{6 6 . 3 2}$ & $\mathbf{2 1 3 . 1 0}$ \\
\hline
\end{tabular}

It is important to emphasize that the samples were taken randomly from the buckets, as the material was deposited in PLANT-B is considered empty. The unit mass represents the mass / volume of the samples for each investigation, therefore: 


$$
\mathrm{UM}=\frac{213.10}{270}=0.79 \mathrm{Kg} / \mathrm{L} \text { ou } 0.79 \mathrm{t} / \mathrm{m}^{3}
$$

Considering the calculation of the masses of materials, we determined the composition of the CW for Ribeirão Preto for residential typology works, as shown in Figure 1:

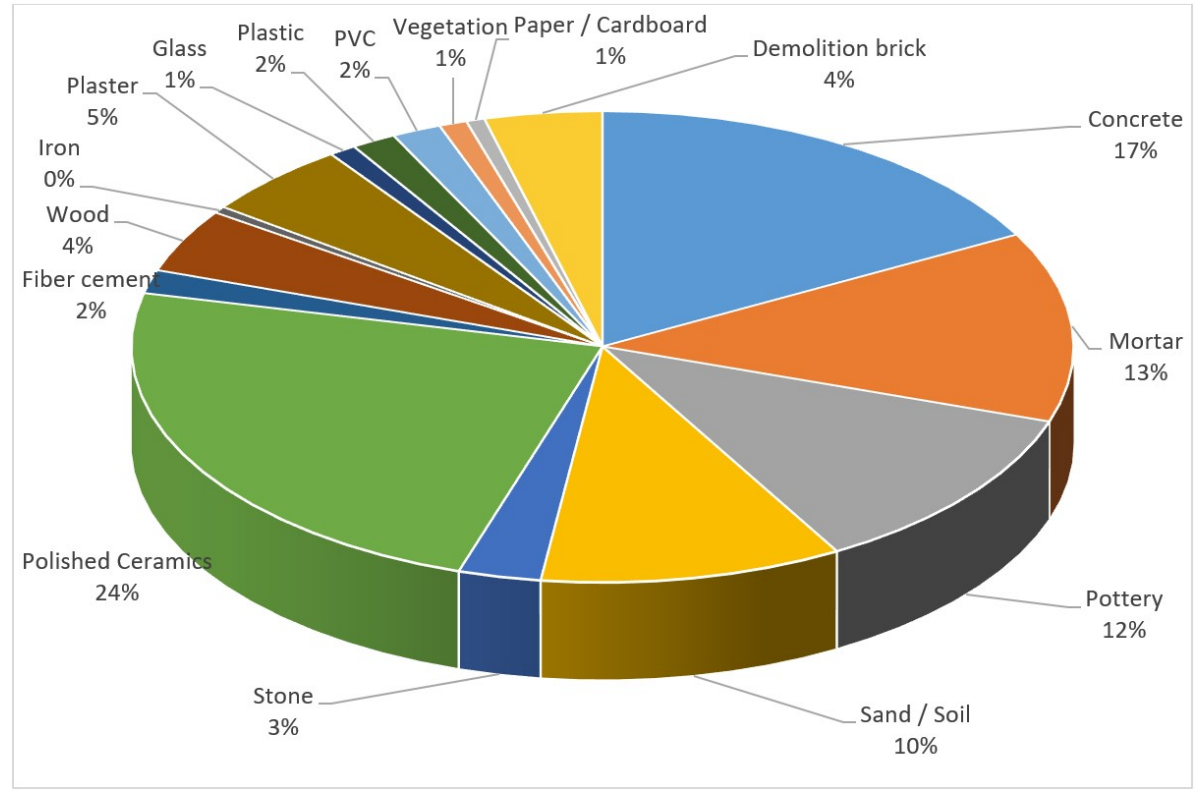

Figure 1. Percentage composition of CW in Ribeirão Preto for residential works.

\subsection{Determination of clandestine disposal points in Ribeirão Preto}

In the municipality of Ribeirão, the disposal of construction waste in irregular places occurs unbridled and constantly growing, which increasingly aggravates the problem in the city, generating strong environmental, sanitation, social and economic impacts.

The main places where irregular discards take place are at the borders of streams, rivers and especially in the peripheral part of the city. A curious fact is that for those who enter in Ribeirão Preto by the main access roads of the South, East and West zones do not face the presence of these residues, but for those who enter in the city through the access roads in the North Zone, immediately perceives the terrible situation of abandonment that Ribeirão Preto faces in relation to the management of Civil Construction Waste and urban cleaning.

In the present work, a survey was carried out of the main areas of CW irregular disposal in the city of Ribeirão Preto, which has the contribution of waste pickers and individuals to aggravate the situation. There was a lack of a policy that would contribute to better management of the CWs and allow more stringent monitoring of waste disposal, which is increasingly aggravating the situation, as accelerated population growth and lack of infrastructure do not accompany pace of city development.

It was observed in the visit to the irregular disposal sites that, as previously mentioned in the present study, in the northern region of the city is the largest number 
of irregular disposal points, a fact that was justified by the region being the least favored of the city. There was also a large concentration of people called pickers, who seek to separate these wastes in order to find objects that they can sell to generate some money to them. However, this situation increasingly aggravates the environmental, social and sanitation problems, because the lack of hygiene and sanitation in the places generate serious diseases for people, such as skin mycoses and others.

In the field research it was verified the lack of supervision regarding the disposal of construction waste in Ribeirão Preto, a fact that was strongly perceived and raised in conversations with the owners of authorized locations for disposal. The main complaint of practically all owners of recycling ATTs and plants was regarding the neglect of the Ribeirão Preto City Hall, since, denounced the places and people, the city did not take the appropriate measures for the case.

Table 3 presents the main locations of $\mathrm{CW}$ irregular disposal, through a survey of areas:

Table 3. Inventory of CW disposal areas in Ribeirão Preto.

\begin{tabular}{cllcc}
\hline Area & \multicolumn{1}{c}{ Place } & \multicolumn{1}{c}{ Neighborhood } & Size & Situation \\
\hline 1 & Avenue Rio Pardo & Ipiranga & $\mathrm{P}$ & Active \\
\hline 2 & Avenue Governor Mario Covas & Simioni & $\mathrm{P}$ & Active \\
& & & $\mathrm{M}$ & Active \\
\hline 3 & Avenue Eduardo A. Matarazzo & Ipiranga & & \\
\hline 4 & Avenue General E. of Figueiredo & Simioni & $\mathrm{M}$ & Active \\
& & & & \\
\hline 5 & Andradas Avenue & Marchesi Garden & $\mathrm{P}$ & Active \\
\hline 6 & Avenue Dra. Nadir Aguiar & Jamil Cury Garden & $\mathrm{M}$ & Active \\
& & & & \\
\hline 7 & Avenue Virgílio Soeira & Paiva Garden & $\mathrm{M}$ & Active \\
\hline 8 & Avenue Wanderley Taffo & Quintino Facci II & $\mathrm{M}$ & Active \\
\hline 9 & Avenue Patriarch & Ribeirão Park & $\mathrm{P}$ & Active \\
\hline 10 & Street Priest Bento Dias Pacheco & Geraldo de Carvalho & $\mathrm{P}$ & Active \\
& & & & \\
\hline 11 & Street Primo Trunk & Virginia Village & $\mathrm{P}$ & Active \\
\hline 12 & Avenue Ernesto Guevara Wool & Orestes Lopes & $\mathrm{M}$ & Active \\
& Serna & & & \\
\hline 13 & Municipal Garden Road & Ribeirão Park & $\mathrm{M}$ & Active \\
& & & & \\
\hline 14 & AlDS slum & Ribeirão Park & $\mathrm{M}$ & Active \\
\hline 15 & Jardinópolis Earth Road & Jardinópolis & Active \\
\hline 16 & Arthur de Jesus Campos Street & Quintino Facci II & Active \\
\hline 17 & Japurá Street & Antonio Galão Street & Ipiranga & Active \\
\hline & Alexandre Balbo & Active \\
\hline 19 & Garden Jockey Club & $\mathrm{P}$ & \\
\hline
\end{tabular}


Table 3. Continued...

\begin{tabular}{|c|c|c|c|c|}
\hline Area & Place & Neighborhood & Size & Situation \\
\hline 20 & Japurá Street & Ipiranga & $\mathrm{P}$ & Active \\
\hline 21 & Acari Leandro Street & José Sampaio Garden & $\mathrm{P}$ & Active \\
\hline 22 & Americo Batista Street & José Sampaio Garden & $\mathrm{P}$ & Active \\
\hline 23 & Francisca Massaro Flour Street & Ribeirânia & $\mathrm{P}$ & Active \\
\hline 24 & Antônio Duarte Nogueira Highway & Alexandre Balbo & $\mathrm{P}$ & Active \\
\hline 25 & Ettore and Aurora Coraucci Avenue & Alexandre Balbo & $\mathrm{P}$ & Active \\
\hline 26 & Estevão Nomelini Avenue & Alexandre Balbo & $\mathrm{P}$ & Active \\
\hline 27 & Ettore and Aurora Coraucci Avenue & Pinus Park & $\mathrm{P}$ & Active \\
\hline 28 & Ettore and Aurora Coraucci Avenue & Alexandre Balbo & $\mathrm{P}$ & Active \\
\hline 29 & Thomaz Alberto Whately Avenue & $\begin{array}{l}\text { Quito Junqueira Industrial } \\
\text { Park }\end{array}$ & $\mathrm{P}$ & Active \\
\hline 30 & Twenty-Fourth Street & Paschoal Innecchi & $\mathrm{P}$ & Active \\
\hline 31 & 5th Street & Paschoal Innecchi & $\mathrm{P}$ & Active \\
\hline 32 & 5th Street & Paschoal Innecchi & $\mathrm{P}$ & Active \\
\hline 33 & Elisa Regina $n$ Street & Paschoal Innecchi & $\mathrm{P}$ & Active \\
\hline 34 & Nájla Bittar Jorge Street & Paschoal Innecchi & $\mathrm{P}$ & Active \\
\hline 35 & Rua Vinte e Quatro & Paschoal Innecchi & $\mathrm{P}$ & Active \\
\hline 36 & Rua Nájla Bitar Jorge & Paschoal Innecchi & $\mathrm{P}$ & Active \\
\hline 37 & Avenida Orestes Lopes de Camargo & Jockey Club & $\mathrm{P}$ & Active \\
\hline 38 & Avenida Dr. Antônio Macário & Servers Park & $\mathrm{P}$ & Active \\
\hline 39 & Estrada de terra Via Ângelo & Servers Park & $\mathrm{P}$ & Active \\
\hline 40 & Avenida José Antônio Ferrarezi & Servers Park & M & Active \\
\hline 41 & Rua Alfredo Pode & Servers Park & $\mathrm{P}$ & Active \\
\hline 42 & Avenida José Antônio Ferrarezi & Servers Park & $\mathrm{P}$ & Active \\
\hline 43 & Avenida Alfredo Ravaneli & Helena Garden & $\mathrm{P}$ & Active \\
\hline 44 & Rua Poe. Fernando Pessoa & Palm Garden & $\mathrm{P}$ & Active \\
\hline 45 & Avenida Alfredo Ravaneli & São Sebastião Park & $\mathrm{P}$ & Active \\
\hline
\end{tabular}

$\mathrm{P}$ - Small, with up to 101.5 meter high height; $\mathrm{M}$ - Medium, between 10 and 501.5 meter high height

The results of this study are fundamental to support the main construction waste management measures in Ribeirão Preto-SP. It is possible to compare the results obtained by the authors with studies conducted in other municipalities, such as Marques (2003), in São Carlos-SP, finding a value of $0.6 \mathrm{t} / \mathrm{m}^{3}$ for the unit mass of civil construction waste and Córdoba. (2010), also in the municipality of São Carlos finding a value of $1.2 \mathrm{t} / \mathrm{m}^{3}$ of $\mathrm{CW}$ unit mass. In this comparison, the present study obtained a value of $0.79 \mathrm{t} / \mathrm{m}^{3}$ of unit mass, which may be justified by the fact that the study takes into account the construction waste directly from the bucket, as it is collected, without any crushing treatment or some recycling process for this analysis. Another comparative aspect refers to the composition of $\mathrm{CW}$ found in the city of Ribeirão PretoSP. Comparing the present work with Pinto (1989), who performed the qualitative 
characterization of the CW from some constructions in the city of São Carlos, obtained the average percentage composition of the materials found in the rubble according to Table 4 below:

Table 4. Average CW composition of the city of São Carlos.

\begin{tabular}{cc}
\hline Material & Average Composition (\%) \\
\hline Mortars & 63.67 \\
\hline Solid brick & 17.98 \\
\hline Concrete & 11.11 \\
\hline Concrete block & 4.23 \\
\hline Concrete tiles & 0.11 \\
\hline Stones & 0.39 \\
\hline Asbestos cement & 1.38 \\
\hline Ground & 0.38 \\
\hline wood & 0.13 \\
\hline Paper and organic material & 0.11 \\
\hline
\end{tabular}

Source: Pinto (1989).

Comparing the results of the present work with Zordan (1997), who carried out the qualitative characterization of the civil construction waste produced in Ribeirão Preto-SP in 1997 , it is possible to verify the evolution of the construction waste generation as well as its evolution. composition according to Table 5 :

Table 5. Average CW composition of the city of Ribeirão Preto-SP (1997).

\begin{tabular}{cc}
\hline Material & Average Composition (\%) \\
\hline Stone & 17.7 \\
\hline Concrete & 37.4 \\
\hline Pottery & 20.8 \\
\hline Polished pottery & 2.5 \\
\hline Mortar & 21.1 \\
\hline Others & 0.5 \\
\hline
\end{tabular}

Source: Zordan (1997).

\section{Conclusions}

One of the major problems facing the municipality of Ribeirão Preto is the high rate of $\mathrm{CW}$ generation, which is growing and generating serious environmental impacts. Despite CONAMA Resolution No. 307 establishing guidelines for the proper management of waste generated, Ribeirão Preto is far from solving the problem, given the high rates of generation and the high rates of irregular disposal in the city, thus the model of Integrated construction waste management in Ribeirão Preto is deficient and has several critical points.

In order to fulfill the main objective of the present study, it is possible to verify through Figure 1, the composition of the civil construction waste from Ribeirão Preto-SP, which indicates the percentage indices of each component. Thus, we can conclude that the component with the highest percentage index is polished ceramics, representing $24 \%$ 
of the residues, just as the lowest indexes generated were plaster, vegetation and paper / cardboard, with $1 \%$ each item. We can conclude that these values are representative when comparing the types of waste generated with the losses that these materials represent, since a finishing material, such as polished ceramic, which, due to the application process, generates many cuts, causing many losses of this material and thus contributing to high rates of waste generation on constructions.

Still regarding the composition of the construction residues found in the present work, we can conclude that the low indexes registered for the plaster, vegetation and paper / cardboard can be justified by the high values of the plaster bucket in Ribeirão Preto-SP. In its logistics, the municipality directs the plaster residues to the landfill of another municipality near the region (Guatapará), thus, the cost of transport increases the buckets with plaster, which in turn are passed on to the builder through high values. With this, there is a huge interest in reducing or even not generating plaster residues on constructions.

Contributing to the objective of the study, an inventory was made of the main clandestine disposal points of construction waste for the municipality of Ribeirão Preto-SP, which was organized in order to identify the disposal site, the neighborhood, the size of the locations and the situation. It was possible to conclude through analysis that all sites are active, with recurrent discards and growth possibility.

The clandestine areas that are being used for the disposal of CW presented in this work are active and in constant use, which indicates the need for studies to implement new CW receiving points. These points should also include the recycling of the collected debris, thus favoring the correct disposal of waste.

Analyzing or inventing the study produced, we can conclude that all neighborhoods where clandestine points of use were identified are listed in the North Zone of the municipality, especially in the suburbs, where the purchasing power of the population is lower, which justifies an attempt proliferation of clandestine disposal locations.

To achieve the secondary objectives of the present work were also raised as disposal areas authorized by the city. It was possible to complete the logo in the city of Ribeirão Preto SP, with a licensing point and the use of construction waste, five transhipment and sorting areas and six recycling plants. There was a need to implement new construction waste residues licensed by the City Hall.

In this context, it was possible to survey or quantify construction waste at one of the disposal sites available for a 4-month period in 2016, obtaining the following values: $1,905 \mathrm{~m}^{3}, 2,313 \mathrm{~m}^{3}, 2,050 \mathrm{~m}^{3}, 749 \mathrm{~m}^{3}$ for September, October, November and December, respectively.

After applying the methodology used in the present study in PLANT-B and relating to the quantities in $\mathrm{kg}$ of the studied buckets, it was possible to determine the unit mass of construction waste. Applying the methodology were selected 3 discarded buckets in PLANT-B, taking $270 \mathrm{~L}$ of sample for analysis. Thus, a total of $213.10 \mathrm{Kg}$ of residues were obtained, which were separated and later weighed to determine the respective percentages and compositions. In this moment it was possible to conclude that, by comparing the studied buckets and their quantities, we had a unit rate of $0.79 \mathrm{Kg} / \mathrm{L}$ or $0.79 \mathrm{t} / \mathrm{m}^{3}$.

Therefore, the present work theoretically and practically showed the subject of CW, raised a parameter of the generation rate, thus contributing information for future studies and pointed out the phases of higher generation of $\mathrm{CW}$. 


\section{References}

Associação Brasileira de Normas Técnicas - ABNT. (2004b). NBR 15112: Resíduos da construção civil e resíduos volumosos - Áreas de transbordo e triagem - Diretrizes para projeto, implantação e operação. Rio de Janeiro: ABNT.

Associação Brasileira de Normas Técnicas - ABNT. (2004c). NBR 15113: Resíduos sólidos da construção civil e resíduos inertes - Aterros - Diretrizes para projeto, implantação e operação. Rio de Janeiro: ABNT.

Associação Brasileira de Normas Técnicas - ABNT. (2004d). NBR 15114: Resíduos sólidos da construção civil - Áreas de Reciclagem - Diretrizes para projeto, implantação e operação. Rio de Janeiro: ABNT.

Associação Brasileira de Normas Técnicas - ABNT. (2004e). NBR 15115: Agregados reciclados de resíduos sólidos da Construção civil - Execução de camadas de pavimentação - Procedimentos. Rio de Janeiro: ABNT.

Associação Brasileira de Normas Técnicas - ABNT. (2004f). NBR 15116: Agregados reciclados de resíduos sólidos da Construção civil - Utilização em pavimentação e preparo de concreto sem função estrutural - Requisitos. Rio de Janeiro: ABNT.

Brasil. (2002). Resolução CONAMA $n^{\circ} 307$, de 05 de julho de 2002. Estabelece diretrizes, critérios e procedimentos para a gestão dos resíduos da construção civil (seção 1, n' 136 , pp. 95-96). Brasília, DF: Diário Oficial da República Federativa do Brasil.

Brasil. (2011). Resolução CONAMA n $n^{\circ}$ 431, de 25 de Maio de 2011. Altera o art. 30 da Resolução no 307, de 5 de julho de 2002, do Conselho Nacional do Meio Ambiente CONAMA, estabelecendo nova classificação para o gesso. Brasília, DF: Diário Oficial da República Federativa do Brasil.

Brasil. (2012). Resolução CONAMA $n^{\circ} 448$, de 19 de Janeiro de 2012. Altera os arts. $2^{\circ}, 4^{\circ}, 5^{\circ}$, $6^{\circ}, 8^{\circ}, 9^{\circ}, 10$ e 11 da Resolução $n^{\circ} 307$, de 5 de julho de 2002, do Conselho Nacional do Meio Ambiente- CONAMA. Brasília, DF: Diário Oficial da República Federativa do Brasil.

Carneiro, F. P., Brum, I. A.S., \& Cassa, J. C. S. (2001). Reciclagem de entulho para produção de materiais para construção. Projeto Entulho Bom. Salvador: EDUFBA/Caixa Econômica Federal.

Castro, M. C. A. A., Schalch, V., Fernandes, J. L., Jr., \& Leite, W. C. A. (1998). Caracterização Física e Granulométrica dos Entulhos Gerados na Construção Civil na cidade de São Paulo. In Anais do Congresso Brasileiro de Engenharia Sanitária e Ambiental. Rio de Janeiro: ABES.

Córdoba, R. E. (2010). Estudo do sistema de gerenciamento integrado de resíduos de construção e demolição do município de São Carlos-SP (Dissertação de mestrado). Escola de Engenharia de São Carlos, Universidade de São Carlos, São Carlos.

Leite, M. B. (2001). Avaliação de Propriedades Mecânicas de Concretos Produzidos com Agregados Reciclados de Resíduos de Construção e Demolição (Tese de doutorado). Universidade Federal do Rio Grande do Sul, Porto Alegre.

Levy, S. M. (1997). Reciclagem do entulho da construção civil, para utilização como agregados para argamassas e concreto (Dissertação de mestrado). Escola Politécnica, Universidade de São Paulo, São Paulo.

Marques, J. C. No. (2003). Diagnóstico para estudo de Gestão de Resíduos de Construção e Demolição do Município de São Carlos -SP (Dissertação de Mestrado em Hidráulica e Saneamento). Escola de Engenharia de São Carlos, Universidade de São Paulo, São Carlos.

Pinto, T.P. (1989). Perdas de materiais em processos construtivos tradicionais. São Carlos: Departamento de Engenharia Civil, Universidade Federal de São Carlos - UFSCar. 
Tavares, L. P. M. (2007). Levantamento e análise da deposição e destinação dos resíduos da construção civil em Ituiutaba, MG (Dissertação de mestrado). Universidade Federal de Uberlândia, Uberlândia.

Zordan, S. E. A. (1997). Utilização do entulho como agregado na confeç̧ão do concreto (Dissertação de Mestrado). Faculdade de Engenharia Civil, Universidade Estadual de Campinas, Campinas. 